\title{
PEMBUATAN KOMPOS MENGGUNAKAN STARTER MIKROBA UNTUK MENINGKATKAN PERTUMBUHAN BIBIT DURIAN KANI DI DESA SUDAJI KECAMATAN SAWAN KABUPATEN BULELENG BALI
}

\author{
N.L. Arpiwi ${ }^{1}$, I.K. Muksin ${ }^{2}$, I.N. Simpen ${ }^{3}$, I.M.S. Negara ${ }^{4}$
}

\begin{abstract}
ABSTRAK
Tujuan kegiatan pengabdian Ipteks bagi Masyarakat ini adalah untuk memanfaatkan kotoran sapi dan limbah pertanian seperti hijauan menjadi pupuk organik Starkompos dengan penambahan starter mikroba. Penggunaan kompos yang ramah lingkungan diharapkan meningkatkan pertumbuhan bibit durian Kani, mengurangi pemakaian pupuk kimia yang harganya mahal, mengurangi polusi tanah dan lingkungan dari residu kimia. Kegiatan melibatkan dua kelompok tani, yaitu kelompok tani Kembang Dwi Suaji di Dusun Rarangan dan kelompok tani Sari Murni di Dusun Kubukili Desa Sudaji Kecamatan Sawan, Kabupaten Buleleng, Bali. Starkompos dibuat dengan cara mencampur kotoran sapi dengan hijauan yang telah dicacah dengan perbandingan 8:2. Starter mikroba bubuk yang disebut StarTmik@OK ditaburkan, pada campuran bahan lapis demi lapis, disiram dengan air, kemudian ditutup rapat dengan terpal. Setelah 14 hari terpal dibuka, kompos dibolak balik dengan cangkul kemudian ditutup lagi. Setelah 30 hari Starkompos matang yang ditandai dengan nilai rasio C : N sebanyak 14,92. Starkompos diberikan kepada bibit durian Kani dengan dosis 2 ton per hektar. Pemberian Starkompos pada bibit durian Kani meningkatkan pertumbuhan secara nyata $(\mathrm{P}<0,05)$. Kesimpulan kegiatan pengabdian ini adalah pembuatan kompos dari kotoran sapi dicampur hijaun dengan penambahan starter mikroba bubuk meningkatkan kandungan nitrogen, fosfat dan kalium yang tersedia bagi tumbuhan. Pemberian Starkompos pada bibit durian Kani meningkatkan keliling batang, tinggi tanaman dan jumlah cabang.
\end{abstract}

Kata Kunci : Starkompos, starter mikroba, bibit, durian kani, Desa Sudaji

\begin{abstract}
The purpose of the community service was to utilize cow manure and agricultural waste such as forage into organic fertilizer called Starcompost with the addition of microbial starter. The use of environmentally friendly Starcompost is expected to increase the growth of Kani durian seedlings, reduce the use of expensive chemical fertilizers, and reduce soil and environmental pollution from chemical residues. The activity involves two groups of farmers, namely Kembang Dwi Suaji in Dusun Rarangan and Sari Murni in Dusun Kubukili Sudaji Village, Sawan District, Buleleng Regency, Bali. Starcompost is made by mixing cow manure with forage with a ratio of 8: 2. Starter microbial powder called StarTmik @ OK was spread over the mixture layer by layer, doused with water then sealed with a tarpaulin. After 14 days the tarpaulin was opened, the compost is turned back with a hoe and then closed again. After 30 days Starcompost ripened which was indicated by $\mathrm{C}: \mathrm{N}$ ratio of 14.92 . Starcompost was applied to the seedlings of durian Kani with a
\end{abstract}

\footnotetext{
${ }^{1}$ Jurusan Biologi Fakultas MIPA Universitas Udayana, Kampus Bukit Jimbaran, Badung, Bali. Email: arpiwi@unud.ac.id

2 Jurusan Biologi Fakultas MIPA Universitas Udayana, Kampus Bukit Jimbaran, Badung, Bali

3 Jurusan Kimia FMIPA Universitas Udayana, Kampus Bukit JImbaran, Badung Bali

${ }^{4}$ Jurusan Kimia FMIPA Universitas Udayana, Kampus Bukit JImbaran, Badung Bali
} 
dose of 2 tons per hectare. Application of Starcompost to Kani durian seedlings increased the growth significantly $(\mathrm{P}<0.05)$. The conclusion was the composting of cow dung mixed with the addition of microbial starter increased the content of nitrogen, phosphate and potassium available to plants. Application of Starcompost to Kani durian seedlings increased the circumference of stems, plant height and number of branches.

Keywords : Starcompost, microbial starter, seedling, Kani durian, Sudaji Village

\section{PENDAHULUAN}

Durian (Durio zibethinus) merupakan tanaman yang berasal dari Asia Tenggara yang beriklim tropika basah seperti Indonesia, Thailand dan Malaysia. Salah satu jenis durian yang sangat popular adalah durian Bangkok varietas Kani atau sering disebut durian Kani (Sarwono 1995). Durian Kani termasuk varietas genjah yang mulai berbuah pada umur $4-5$ tahun dengan ukuran buah besar besar. Untuk itu budidaya durian Kani perlu terus digalakkan untuk memenuhi permintaan pasar yang dimulai dari usaha pembibitan untuk menghasilkan bibit unggul bermutu. Pembibitan durian Kani biasanya dilakukan dengan tehnik penempelan/okulasi atau penyambungan antara batang bawah dan batang atas (Purnomosidi dkk 2006; Prastowo dkk 2007).

Desa Sudaji merupakan salah satu desa di utara pulau Bali tepatnya di Kecamatan Sawan, Kabupaten Buleleng memenuhi persyaratan ideal untk pembibitan berbagai jenis tanaman hortikultura termasuk durian Kani. Hal ini karena suhu udara sejuk, kelembaban tinggi dan curah hujan cukup. Usaha pertanian yang sangat berkembang di Desa Sudaji adalah pembibitan tanaman hortikultura seperti jeruk, rambutan, mangga, jambu, sirsak, sawo, wani, lengkeng, jambu biji, durian dan lain lain. Durian Bangkok varietas Kani merupakan salah satu produk unggulan dengan permintaan yang semakin meningkat dari tahun ke tahun.

Secara umum pembibitan tanaman hortikultura di desa Sudaji sudah berlangsung bertahun - tahun. Hal ini menyebabkan kandungan unsur hara tanah yang sangat diperlukan tanaman jumlahnya semakin menurun yang berdampak pada penurunan kesuburan tanaman. Dalam manajemen kesuburan tanah, para petani menggunakan pupuk kimia dengan dosis sebagai berikut. Untuk bibit kecil yang berumur dibawah satu tahun diberikan pupuk ZA dan Phonska dengan dosis masing masing sebanyak $100 \mathrm{~kg} /$ hektar. Untuk bibit besar berumur lebih dari satu tahun diberi pupul ZA, Phonska dan urea masing - masing sebanyak $100 \mathrm{~kg}$ per hektar. Kondisi bibit yang kurang subur khususnya bibit durian Kani menyebabkan pertumbuhanya lambat sehingga diperlukan waktu lebih lama untuk bisa dijual. Hal ini berdampak pada penurunan pendapatan petani penangkar bibit.

Selain harganya yang terus meningkat, penggunaan pupuk kimia dalam jangka waktu lama menimbulkan masalah lingkungan, misalnya pencemaran tanah dan kerusakan struktur tanah (Lestari 2009). Pemberian pupuk nitrogen (N) pada tanaman hanya diserap sebanyak $35 \%$ oleh perakaran, sisanya akan mengalami leaching atau pencucian bersama air irigasi dan air hujan dan mencemari sumber - sumber air seperti danau, kolam dan mata air dan menyebabkan penurunan kualitas air dan eutrofikasi (Andews et al., 2009).

Di Desa Sujadi kotoran sapi jumlahnya melimpah dan selama ini hanya digunakan secara langsung untuk memupuk tanaman tanpa fermentasi oleh starter mikroba. Hal ini menimbulkan masalah, misalnya kematian tanaman karena penggunaan kotoran sapi yang belum difermentasi menghasilkan panas akibat kerja mikroba anaerob. Kandungan unsur hara kotoran sapi tanpa starter mikroba jumlahnya kurang bisa memenuhi kebutuhan tanaman dan memerlukan waktu yang lebih lama untuk bisa diserap oleh tanaman (Murbandono 1992; Nuhayati 2010). Selain itu limbah pertanian seperti serasah, tongkol jagung, jerami padi juga melimpah tetapi belum dikelola untuk 
meningkatkan nilai ekonominya. Bahan - bahan tersebut bisa dijadikan kompos dengan sentuhan teknologi sterter mikroba.

\section{METODE PELAKSANAAN}

Tahapan pelaksaanaan kegiatan pengabdian kepada masyrakat ini meliputi: sosialisasi ke kelompok tani mitra untuk merumuskan permasalahan mitra, pelatihan, pendampingan, dan evaluasi keberhasilan program pengabdian di lapangan. Pembuatan Starkompos dilakukan bersama kelompok tani mitra, yaitu kelompok tani Kembang Dwi Suaji di Dusun Rarangan dan kelompok tani Sari Murni di Dusun Kubukili Desa Sudaji Kecamatan Sawan, Kabupaten Buleleng, Bali. Lahan pengomposan diberi atap terpal agar terlindung dari paparan sinar matahari yang berlebihan dan air hujan. Limbah pertanian yang berupa hijauan dicacah untuk mengecilkan ukuran sehingga mempercepat proses dekomposisi oleh mikroorganisme. Hijaun dicampur dengan kotoran sapi dengan perbandingan $2: 8$. Untuk satu ton bahan diperlukan hijauan sebanyak $200 \mathrm{~kg}$, kotoran sapi sebanyak 800 kg dan starter mikroba bubuk StarTmik@OK sebanyak 2 kg. Bahan - bahan diaduk menggunakan cangkul hingga tercampur dengan merata. Starter mikroba bubuk ditaburkan pada campuran bahan lapis demi lapis, kemudian disiram dengan air untuk menjaga kelembaban (Gambar 1a). Campuran ditutup rapat dengan terpal (Gambar 1b) dan dibiarkan selama 14 hari. Setelah 14 hari terpal dibuka, kompos dibolak balik dengan cangkul kemudian ditutup lagi dengan terpal. Setelah 30 hari Starkompos sudah matang, terpal dibuka dan kompos dibiarkan selama 2 minggu sebelum diberikan kepada tanaman. Kompos yang permukaannya agak memadat kemudian digemburkan dengan cangkul. Kandungan unsur hara dalam Starkompos dianalisis di Laboratorium Ilmu Tanah, Fakultas Pertanian Universitas Udayana.
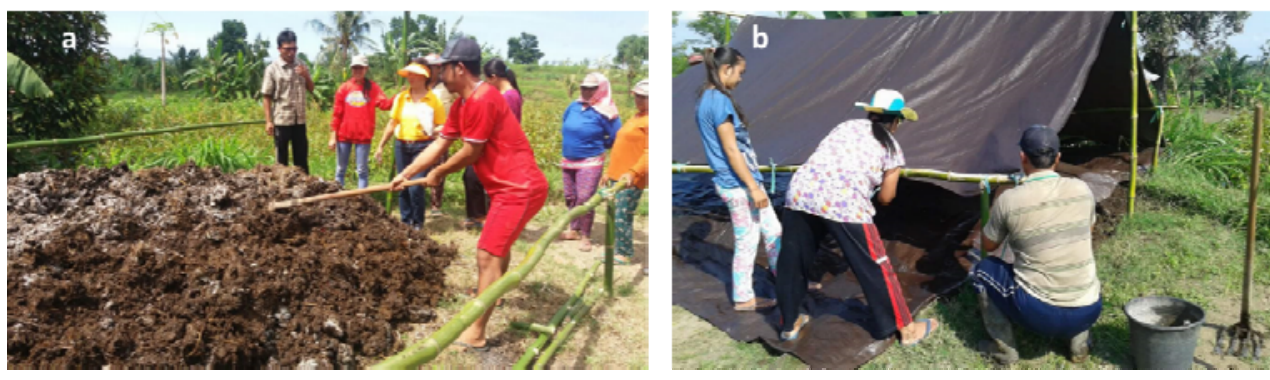

Gambar 1a. Pencampuran hijauan yang telah dicincang dengan kotoran sapi dan starter mikroba bubuk untuk pembuatan Starkompos, 1b. Bahan - bahan kopos yang telah tercampur ditutup dengan terpal

Starkompos yang sudah matang (Gambar 2a) diberikan pada bibit durian Kani sebanyak 2 ton per hektar. Caranya adalah dengan menaburkan Starkompos pada parit - parit pembibitan yang diintegrasikan dengan pengairan (Gambar 2b). Kontak langsung Starkompos dengan batang tanaman tidak direkomendasikan untuk menghindari pengaruh panas yang mungkin dilepaskan oleh Starkompos yang nantinya berdampak buruk bagi tanaman. Pemberian Starkompos dapat diulang setelah enam bulan dengan dosis yang diturunkan menjadi satu per hektar. Pertumbuhan bibit durian Kani diamati selama 4 bulan mulai saat aplikasi Starkompos. Pengukuran parameter pertumbuhan bibit meliputi: tinggi tanaman, diameter batang dan jumlah cabang menghasilkan daun. 


\section{HASIL DAN PEMBAHASAN}

\subsection{Starkompos yang Dihasilkan}

Produk berupa kompos yang disebut Starkompos telah tercapai dengan tekstur gembur dan berwarna warna hitam (Gambar 2a). Hasil analisis terhadap kandungan unsur hara Strakompos menunjukkan dengan $\mathrm{pH} 5,64$, kandungan $\mathrm{C}$ organik sebanyak $22,38 \%$, $\mathrm{N}$ total sebanyak $1,50 \%$, P tersedia 965,34 ppm, K tersedia 8087,76 ppm, Daya Hantar Listrik (DHL) 5,64 mmhos/cm dan kandungan air 14,88\%. Menurut SNI 9-7030-2004 ciri dari kematangan kompos adalah warna hitam serta memiliki tekstur seperti tanah dan berbau seperti tanah. Starkompos telah memenuhi ketentuan SNI 2004 sebagai kompos yang matang. Kandungan C organik Starkompos sebanyak $27,37 \%$ tergolong sangat tinggi jika dibandingkan dengan SNI yang mensyaratkan 9,8-32\%. Kandungan $\mathrm{C}$ organik yang tinggi merupakan ciri khas pupuk organik yang membedakannya dengan pupuk anorganik. Pemberian pupuk organik seperti Starkompos pada tanaman menambah bahan organik tanah. Bahan organik berperan penting untuk memperbaiki sifat fisika, kimia dan biologi tanah. Bahan organik memperbaiki sifat fisik tanah, diantaranya memperbaiki struktur tanah, meningkatkan kapasitas tanah untuk penyimpanan air, memperbaiki porositas, aerasi dan infiltrasi sehingga memudahkan akar menembus tanah dalam meyerap unsur hara (Suwardjo dkk, 1984). Secara kimia, bahan organik meningkatkan kapasitas tanah menyangga $\mathrm{pH}$ dan meningkatkan daya tukar kation (Sukristiyonubowo dkk, 1993). Secara biologis bahan organik merupakan sumber energi bagi mikroorganisme tanah, sehingga penambahan bahan organik meningkatkan aktivitas biologis dan jumlah mikroba tanah (Mubandono, 1992).

Rasio C : N Starkompos sebanyak 14,92 telah memenuhi nilai yang disyaratkan oleh SNI 9-70302004 sebanyak $10-20$. Nilai rasio C : N sebanyak 14,92 mengindikasikan kematangan kompos serta proses dekomposisi bahan - bahan organik telah berjalan sempurna sehingga kompos siap diberikan kepada tanaman.
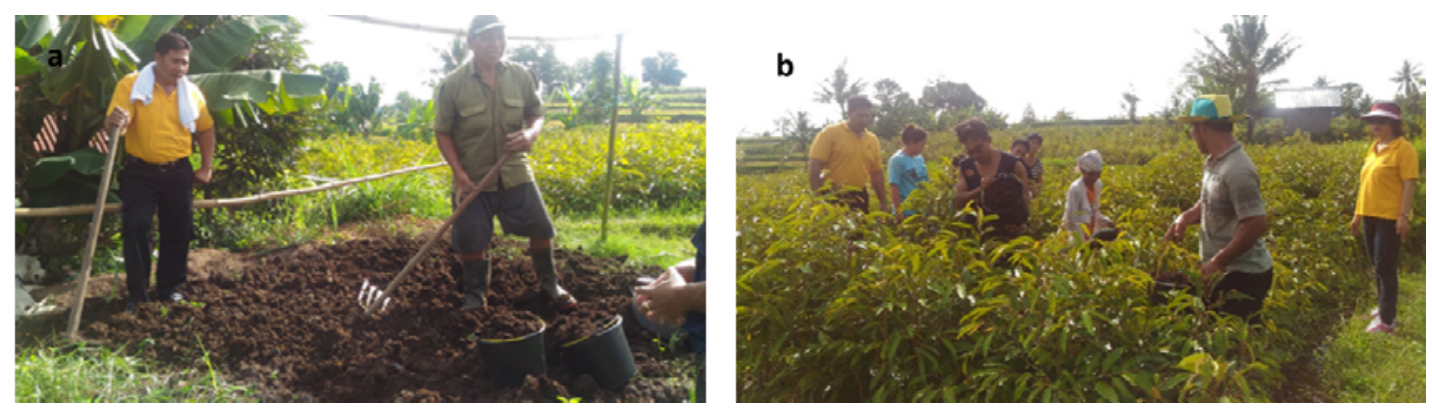

Gambar 2a. Starkompos yang sudah matang memiliki tekstur gembur dan berwarna hitam. 2b. Starkompos diberikan pada bibit durian Kani yang diintegrasikan dengan sistem pengairan.

Kandungan C organik Starkompos sebanyak $27,37 \%$ tergolong sangat tinggi jika dibandingkan dengan SNI yang mensyaratkan $9,8-32 \%$. Kandungan $\mathrm{C}$ organik yang tinggi merupakan ciri khas pupuk organik yang membedakannya dengan pupuk anorganik. Pemberian pupuk organik seperti Starkompos pada tanaman menambah bahan organik tanah. Bahan organik berperan penting untuk memperbaiki sifat fisika, kimia dan biologi tanah. Bahan organik memperbaiki sifat fisik tanah, diantaranya memperbaiki struktur tanah, meningkatkan kapasitas tanah untuk penyimpanan air, memperbaiki porositas, aerasi dan infiltrasi sehingga memudahkan akar menembus tanah dalam meyerap unsur hara (Suwardjo dkk, 1984). Secara kimia, bahan organik meningkatkan kapasitas tanah menyangga $\mathrm{pH}$ dan meningkatkan daya tukar kation (Sukristiyonubowo dkk, 1993). Secara biologis bahan organik merupakan sumber energi bagi mikroorganisme tanah, sehingga 
penambahan bahan organik meningkatkan aktivitas biologis dan jumlah mikroba tanah (Mubandono, 1992).

Rasio C : N Starkompos sebanyak 29 masih tergolong tinggi jika dibandingkan dengan nili yang disyaratkan oleh SNI 9-7030-2004 sebanyak 10 - 20. Tingginya nilai rasio C : N pada Starkompos mengindikasikan bahwa masih diperlukan waktu yang lebih lama untuk proses dekomposisi kotoran sapi yang dicampur hijauan.

Penggunaan kompos dalam usaha pembibitan durian Kani lebih menguntungkan secara ekonomi dibandingkan menggunakan pupuk kimia. Biaya penggunaan pupuk kimia dalam pembibitan durian Kani untuk satu hektar lahan disajaikan pada tabel 2.

Tabel 2. Biaya Pupuk Yang Diperlukan Untuk Pembibitan Durian Kani Pada Lahan Seluas Satu Hektar

\begin{tabular}{|l|c|r|r|}
\hline Jenis pupuk & $\begin{array}{c}\text { Dosis per hektar } \\
(\mathbf{k g})\end{array}$ & $\begin{array}{c}\text { Harga (Rp) per } \\
\text { sak @ 50 kg }\end{array}$ & \multicolumn{1}{c|}{ Total } \\
\hline Ponshka & 400 & 150.000 & 1.200 .000 \\
\hline ZA & 200 & 180.000 & 720.000 \\
\hline Urea & 100 & 150.000 & 300.000 \\
\hline & & Total & $\mathbf{2 . 2 2 0 . 0 0 0}$ \\
\hline
\end{tabular}

Dapat dilihat dari tabel 2 diatas bahwa biaya yang diperlukan untuk membeli pupuk untuk pembibitan durian Kani seluas satu hektar adalah Rp. 2.220.000. Bila dibandingkan dengan penggunaan Starkompos yang dibuat sendiri oleh petani dari kotoran sapi yang dihasilkan sendiri ditambah starter mikroba maka diperlukan 2 (dua) ton kompos per hektar. Biaya starter mikroba untuk membuat dua ton Starkompos adalah Rp. 400.000 sehingga petani bisa menghemat Rp. 1.800.000 dari biaya pupuk. Penggunaan kompos juga bisa memperbaiki struktur tanah dan menambah mikroorganisme berguna sehingga meningkatkan ketersediaan unsur hara yang berguna bagi tumbuhan.

\subsection{Pertumbuhan Bibit Durian Kani Setelah Pemberian Starkompos}

Bibit durian Kani mengalami pertumbuhan pesat setelah diberikan Starkompos (Tabel 3). Berdasarkan hasil analisis uji $\mathrm{T}$ pemberian kompos berpengaruh nyata $(\mathrm{P}<0,05)$ terhadap peningkatan keliling batang, tinggi tanaman dan jumlah cabang bibit durian Kani

Tabel 3. Pertumbuhan Bibit Durian Kani Tanpa Dan Dengan Pemberian Starkompos

\begin{tabular}{|l|c|c|c|}
\hline \multicolumn{1}{|c|}{ Perlakuan } & Keliling batang $(\mathrm{cm})$ & Tinggi tanaman $(\mathrm{cm})$ & Jumlah cabang \\
\hline Kontrol & $4,34 \pm 0,13$ & $65,40 \pm 1,61$ & $6,40 \pm 0,37$ \\
\hline Starkompos & $6,16 \pm 0,22$ & $80,10 \pm 1,70$ & $7,60 \pm 0,30$ \\
\hline
\end{tabular}

\section{KESIMPULAN DAN SARAN}

Adapun yang dapat disimpulkan dalam kegiatan pengabdian ini adalah:

1. Kegiatan pengabdian kepada masyarakat ini telah mengahasilkan Starkompos yang terbuat dari kotoran sapi dan hijaun dengan perbandingan $8: 2$ dengan penambahan starter mikroba padat dan pupuk organik hayati cair. Starkompos mengandung N, P tersedia dan K tersedia lebih tinggi dari pada kotoran sapi tanpa diberikan starter mikroba. 
2. Pemberian Starkompos dengan dosis 2 ton per hektar pada bibit durian Kani meningkatkan pertumbuhan bibit yang meliputi : keliling batang, tinggi tanaman dan jumlah cabang.

Saran yang diberikan adalah untuk lebih mensosialisakan penggunaan kompos untuk kegiatan pertanian sehingga akan mengurangi dampak perusakan tanah maupun pencemaran sumber sumber perairan akibat penggunaan pupuk kimia. Selain itu penggunaan kompos dapat menghemat biaya produksi pertanian karena tidak perlu memebeli pupuk melainkan memanfaatkan limbah kotoran ternak yang ketersediaannya melimpah.

\section{UCAPAN TERIMAKASIH}

Penulis mengucapkan terimakasih yang amat mendalam kepada Kemenristekdikti yang telah mendanai kegiatan pengabdian kepada masyarakat melalui skema Ipteks Bagi Masyarakat (IbM) dan kepada LPPM Universitas Udayana yang memfasilitasi kegiatan ini. Terimakasih juga kami sampaikan kepada kedua mitra IbM yaitu Kelompok Tani Kembang Dwi Suaji di Dusun Rarangan dan Kelompok Tani Sari Murni di Dusun Kubukili, Desa Sudaji, Kecamatan Sawan, Kabupaten Buleleng, Bali atas kerjasamanya selama pelaksanaan program IbM.

\section{DAFTAR PUSTAKA}

Andrews, M., P.J. Lea, J.A. Raven, R.A. Azevedo (2009) Nitrogen Use Efficiency. 3. Nitrogen Fixation: Genes and Cost. Ann. Appl. Biol. Vol.155, pp. 1-13.

Lestari, A.P. (2009) Pengembangan Pertanian Berkelanjutan Melalui Substitusi Pupuk Anorganik Dengan Pupuk Organik. Jurnal Agronomi. Vol. 13, pp. 138-44.

Murbandono H.S.I. (1992) Membuat Kompos. Penebar Swadaya, Jakarta.

Nurhayati (2010) Pemanfaatan Kompos Sampah Pasar Untuk Budidaya Sawi Organik. Jurusan Agroteknologi Fakultas Pertanian Universitas Islam Sumatera Utara, Medan.

Prastowo, N.H., J.M. Roshetko, G.E.S. Maurung, E. Nugraha, J.M. Tukan, F. Harum (2006) Tehnik Pembibitan dan Perbanyakan Vegetatif Tanaman Buah. Word Agroforestry Center dan Winrock International. Bogor.

Purnomosidi, P., Suparman, J.M. Roshetko, Mulawarman (2007) Perbanyakan dan Budidaya Tanaman Buah - Buahan Durian, Mangga, Jeruk, Melinjo dan Sawo Pedoman lapang. Edisi kedua. Word Agroforestry Center dan Winrock International. Bogor.

Sarwono, B. (1995) Ragam Varietas durian budidaya.Trubus Edisi Desember No 313 Tahun ke XXVI.

Sukristiyonubowo, Mulyadi, P. Wigena, dan A. Kasno. (1993) Pengaruh Penambahan Bahan Organik, Kapur, dan Pupuk NPK terhadap Sifat Kimia Tanah dan Hasil Kacang Tanah. Pemberitaan Penel Tanah dan Pupuk Vol 11, pp.1-6.

Sutinah (2013) Pengujian Kandungan Unsur Hara Dalam Kompos yang Berasal dari Serasah Tanaman Jagung Manis (Zea mays saccharata). Jurnal Ilmiah Pertanian Vol.3, pp.15-25.

Suwardjo, H., A. Abdurachman, dan Sutono. (1984) Pengaruh Mulsa dan Pengelolaan Tanah terhadap Produktivitas Tanah Podsolik Merah Kuning Lampung. Pemberitaan Penel. Tanah dan Pupuk Vol.3, pp.12-16. 